Овчинніков Д.В.

Національний т ранспорт ний університ ет, ДП «Держ авт от рансНДІпроект »

\title{
ВПЛИВ СКЛАДУ СУМІШЕВОГО БЕНЗИНУ НА ЕНЕРГЕТИЧНІ ПОКАЗНИКИ ТА ПАЛИВНУ ЕКОНОМІЧНІСТЬ АВТОМОБІЛІВ З РІЗНИМИ СИСТЕМАМИ ЖИВЛЕННЯ ДВИГУНА
}

\footnotetext{
У роботі викладено результати теоретичних та експериментальних досліджень впливу бензину 3 високим вмістом біоетанолу на показники роботи двигунів та автомобілів з різними системами живлення.

Основна увага приділена використанню такого бензину на автомобілях обладнаних карбюраторною системою живлення. Показано зміни основних показників роботи автомобіля, зокрема показників паливної економічності.

В результаті експериментальних досліджень встановлено, що при незмінному регулюванні карбюратора збільшення вмісту спирту в бензині до 36 \% приводить до значного збіднення паливоповітряної суміші, пропусків робочих циклів, зростання концентрацій незгорілих вуглеводнів та зниження потужності двигуна. Для поліпшення показників роботи автомобілів 3 карбюраторною системою живлення двигуна за роботи на бензині зі значною добавкою спиртових сполук запропоновано змінювати регулювання паливної системи в сторону збагачення паливо-повітряної суміші збільшенням пропускної здатності паливних жиклерів. При відповідному регулюванні паливної системи зі збільшенням вмісту спирту в бензині двигун працює стабільно без пропусків робочих циклів. Незначно зменшується максимальна потужність двигуна та зростає витрата палива, що можна пояснити збідненням паливної суміші при збільшенні вмісту спирту в бензині.

Отримано поліноміальні залежності показників роботи двигуна від концентрації спиртових сполук, крутного моменту та частоти обертання двигуна. Вони дозволяють описати двигун як джерело енергії, споживача палива, повітря та забруднювача навколишнього середовища в навантажувальних режимах роботи та режимах активного і примусового холостих ходів, що необхідно для розрахунку показників автомобілів в русі згідно Модифікованим Європейським їздовим циклом. Представлені результати стендових випробувань автомобіля 3АЗ-1102.

Ключові слова: біоетанол, спиртові сполуки, бензиновий двигун, паливна економічність, стендові випробування.
}

\section{ВСТУП}

На автомобільному транспорті найбільшого розповсюдження набули легкові автомобілі. Основні типи силових установок, які застосовуються це - двигуни 3 іскровим запалюванням та дизелі. Частка електромобілів збільшується, але за відсутності відповідної розвиненої інфраструктури досить повільно. Окремо слід згадати про автомобілі з гібридною силовою установкою, але основним джерелом енергії в ній залишається двигун внутрішнього згоряння.

За останні роки спостерігається тенденція збільшення частки легкових автомобілів обладнаних двигунами 3 іскровим запалюванням в порівнянні 3 дизелями. Це пояснюється вдосконаленням конструкції цих двигунів i, як наслідок, збільшенням питомої потужності та зменшенням питомої витрати палива, а також більш ліпшими екологічними показниками.

Зважаючи на постійне збільшення кількості автомобілів однією 3 гострих проблем $є$ розширення паливної бази. Основними видами пального $є$ бензин, дизельне паливо та зріджений нафтовий газ. Враховуючи постійне зростання цін на нафтопродукти одним 3 можливих рішень $\epsilon$ застосування палив 3 відновлюваних джерел енергії. До таких палив відносять біопаливо, основою для виробництва якого $є$ відходи харчової, сільськогосподарської або деревообробної промисловості. Найближчими замінниками звичного бензину є спиртові палива, зокрема біоетанол. Біоетанол використовується як основне паливо так і в якості добавки до бензину. При використанні біоетанолу як основного палива необхідно вносити зміни до конструкції двигуна. Найбільш доступним шляхом використання біоетанолу $є$ добавка його до бензину. Розміри добавки біоетанолу до бензину безперервно збільшуються, в даний час на автозаправних станціях України доступний бензин 3 добавкою біоетанолу 40\%. Використання таких бензинів можливе не для всіх двигунів, які 
використовуються в експлуатації, зокрема для двигунів з карбюраторною системою живлення. Тому необхідно визначати шляхи можливого використання цих бензинів для таких двигунів.

\section{АНАЛІЗ ЛІТЕРАТУРНИХ ДАНИХ ТА ПОСТАНОВКА ПРОБЛЕМИ}

Результати досліджень по використанню добавок спиртових сполук до бензину наведено в ряді робіт. Питання розширення паливної бази та зменшення споживання палив нафтового походження за рахунок спиртів набуло актуальності ще у 30-ті роки минулого сторіччя [1]. Привабливим у використанні спиртів в якості моторних палив в нашій країні $є$ широка сировинна база і наявність посівних площ в достатній кількості для їх виробництва [2]. Світові тенденції на ринку альтернативних палив свідчать про те, що в останні роки виробництво біоетанолу стрімко зросло у порівнянні з іншими видами біопалив $[3,4]$.

В Україні у період з 1998 по 2006 роки проведено широкі дослідження 3 використання добавок біоетанолу до бензину [5]. За результатами цих досліджень у 2000 році був розроблений Галузевий стандарт України на сумішеві бензини [6].

Вплив добавки біоетанолу до штатного бензину на показники роботи двигуна встановлено в дослідженнях $[7,8,9]$. В цих роботах величина добавки етанолу не перевищувала $20 \%$. Встановлено, що така добавка практично не впливає на показники роботи сучасного двигуна 3 системою впорскування бензину і зворотнім зв'язком [10]. В той же час навіть така добавка $\epsilon$ причиною зміни показників роботи двигуна 3 карбюраторною системою живлення.

\section{ЦІЛЬ ТА ЗАДАЧІ ДОСЛІДЖЕННЯ}

У зв'язку з тим, що на даний момент, як зазначалося вище, на автозаправних станціях України $\epsilon$ в наявності бензин 3 добавкою 40\% кисневмісних сполук, в складі яких більше $75 \%$ етанолу та близько $25 \%$ ізобутилового спирту, питання щодо впливу такого сумішевого бензину на експлуатаційні показники автомобілів обладнаних двигунами 3 іскровим запалюванням потребує поглибленого вивчення.

\section{РЕЗУЛЬТАТИ ДОСЛІДЖЕНЬ}

Для оцінки впливу бензо-спиртових сумішей на експлуатаційні показники автомобіля (розрахунковий метод) була розроблена математична модель. Основу моделі складають алгебраїчні рівняння, що описують двигун як джерело енергії, споживача палива, повітря та забруднювача навколишнього середовища в навантажувальних режимах роботи та режимах активного i примусового холостих ходів тощо, та диференціальні рівняння режимів руху автомобіля для математичного описання виконання автомобілем Модифікованого Європейського їздового циклу згідно з Правилами ЕЭК ООН № 83-05 з розрахунком паливо-економічних та екологічних показників його роботи при живленні як товарним так і сумішевими бензинами. Нижче наведено приклад диференціального рівняння тягового балансу для розганяння автомобіля при зблокованому зчепленні.

$$
\frac{d V}{d t}=\frac{1}{\delta\left(m_{0}+m_{6}\right)}\left[\frac{M_{K H} \cdot U_{i} \cdot U_{p} \cdot \eta_{T}}{r_{\not}}-P_{f} \pm P_{i}-P_{w}\right],
$$

де $\eta_{T}$ - ККД трансмісіі;

$\delta$ - коефіцієнт врахування мас, які обертаються;

$P_{f}-$ сила опору коченню автомобіля, Н;

$P_{i}$ - сила опору підйому, Н;

$P_{w}$ - сила опору повітря, Н;

$m_{0}-$ маса автомобіля, кг;

$m_{в}-$ маса вантажу, кг; 
$M_{K H}$ - величина крутного моменту за неусталеного режиму роботи двигуна, $\mathrm{H} ·$ м;

$U_{i}$ - передаточне число коробки передач;

$U_{p}$ - передаточне число головної передачі;

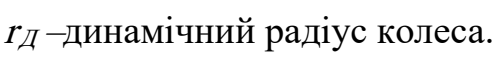

Враховуючи, що в Україні на даний момент окрім автомобілів з бензиновими двигунами 3 системою впорскування та зворотнім зв'язком в експлуатації перебувають автомобілі 3 карбюраторною системою живлення для отримання вихідних даних математичної моделі роботи двигуна на бензині з різним вмістом біоетанолу проведено два три-факторних експерименти. Перший - на двигуні VW BBY з системою впорскування та зворотнім зв'язком, другий - на двигуні МеM3-245 із карбюраторною системою живлення. В результаті отримано залежності годинної і питомої витрат палива та концентрацій шкідливих речовин від крутного моменту, частоти обертання і концентрації спиртових сполук у бензині. Отримані залежності зміни показників роботи двигунів від вмісту біоетанолу в бензині дозволяють створити уточнену математичну модель руху автомобіля за режимами Модифікованого Свропейського їздового циклу при використанні сумішевого бензину зі значними добавками біоетанолу. Нижче наведено загальний вигляд залежності питомої витрати палива від концентрації спиртових сполук, крутного моменту та частоти обертання двигуна.

$g e=a_{0}+a_{1} \cdot x_{1}+a_{2} \cdot x_{2}+a_{3} \cdot x_{3}+a_{11} \cdot x_{1}^{2}+a_{22} \cdot x_{2}^{2}+a_{33} \cdot x_{3}^{2}+a_{12} \cdot x_{1} \cdot x_{2}+a_{13} \cdot x_{1} \cdot x_{3}+a_{23} \cdot x_{2} \cdot x_{3}$,

де, $a_{0}, a_{1}, a_{2}, a_{11}, a_{22}, a_{33}, a_{12}, a_{13}, a_{23}$ - коефіцієнти апроксимації.

Для двигуна МеМЗ-245 ці коефіцієнти дорівнюють: $a_{0}=373,248, a_{1}=81,344, a_{2}=7,967, a_{11}=-5,17$, $a_{22}=35,285, a_{33}=241,085, a_{12}=15,598, a_{13}=52,752, a_{23}=63,317$;

$x_{1}, x_{2}, x_{3}-$ фактори ( $x_{1}-$ концентрація спиртових сполук, $x_{2}-$ частота обертання двигуна, $x_{3}-$ крутний момент). Графічно залежність показана на рисунку 1.

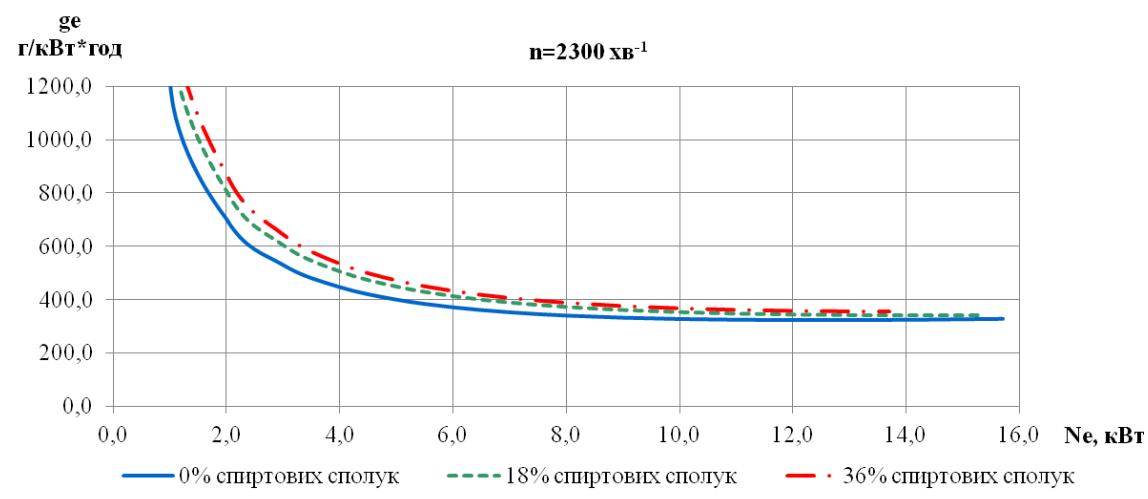

Рисунок 1 - Навантажувальна характеристика двигуна МеМ3-245, згідно математичної моделі роботи двигуна

Згідно отриманих залежностей встановлено зменшення ефективної потужності двигуна до $12 \%$ в режимі повного навантаження та збільшення годинної і питомої витрат палива у всьому робочому діапазоні двигуна при роботі його на сумішевому бензині із значною часткою біоетанолу. Збільшення питомої витрати палива при повному навантаженні складає близько 8\%. Також додатково встановлено, що за штатної системи живлення при температурі навколишнього середовища під час випробування в межах від $10^{\circ} \mathrm{C}$ до $15^{\circ} \mathrm{C}$ спостерігаються пропуски робочих циклів та різке зменшення потужності внаслідок збіднення робочої суміші більше допустимих значень (рисунок 2,3) [11], це обумовлюється фізичними властивостями біоетанолу. 


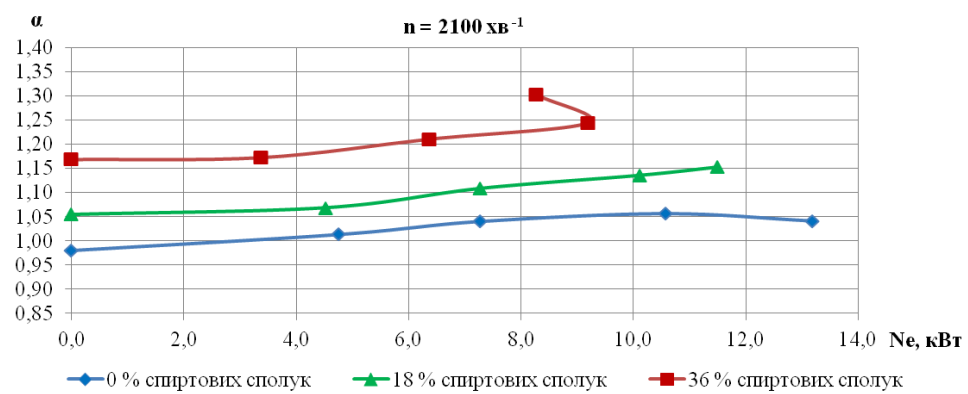

Рисунок 2 - Експериментальні значення коефіцієнту надміру повітря для різних за величиною добавках спиртових сполук двигуна МеМЗ-245

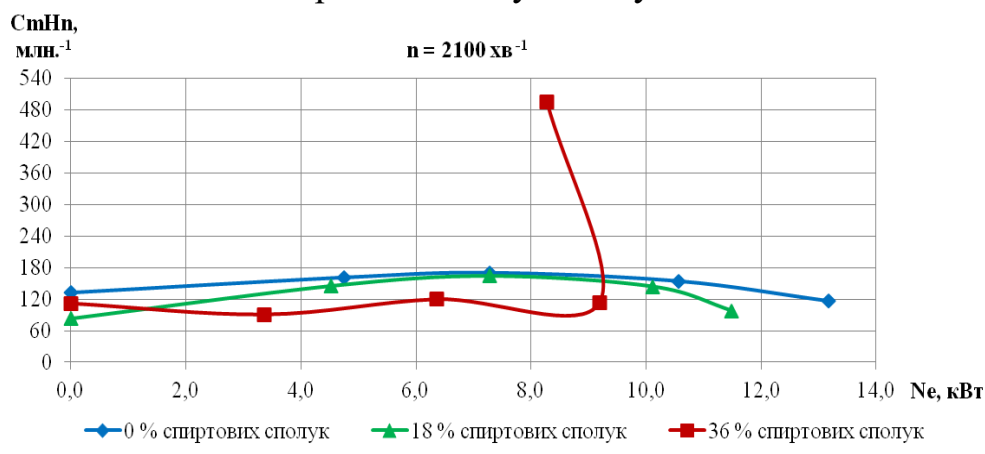

Рисунок 3 - Експериментальні значення концентрацій вуглеводнів у відпрацьованих газах млн ${ }^{-1}$ двигуна МеМ3-245 для різних за величиною добавках спиртових сполук в бензині

Для перевірки адекватності математичної моделі проведено стендові випробування автомобіля 3АЗ-1102 з двигуном МеМ3-245 за Модифікованим Європейським їздовим циклом (рисунок 4) який складається із чотирьох наборів міських режимів і набору режимів, який імітує рух автомобіля за містом на товарному бензині А-95 і сумішевому бензині А-95 E40 (метанол - 2,7\%, етанол - 31,2\%, ізобутиловий спирт - 6,1\% за об'ємом) та знято навантажувальні характеристики (рисунок 5). Під час випробувань в першу чергу визначали показники паливної економічності. Стендові випробування автомобіля проводили у лабораторії ДП “ДержавтотрансНДІпроект" (рисунок 6) на моделюючому роликовому стенді AVL тип RPL1220/12C23M17/APM150. Витрату палива вимірювали гравіметричним витратоміром AVL 733S (рисунок 7). Відбір відпрацьованих газів здійснювався за допомогою дослідної повно-потокової системи відбору проб на основі універсальної системи відбору проб постійного об'єму (CVS) моделі EMMS-CVS-010. Аналіз відпрацьованих газів проводили газоаналітичною системою MEXA-7400DEGR вимірювання концентрації нормованих забруднюючих речовин у газах.

В середньому за випробування витрата бензину А-95 E40 на 20\% більша ніж бензину А-95 (таблиця 1).

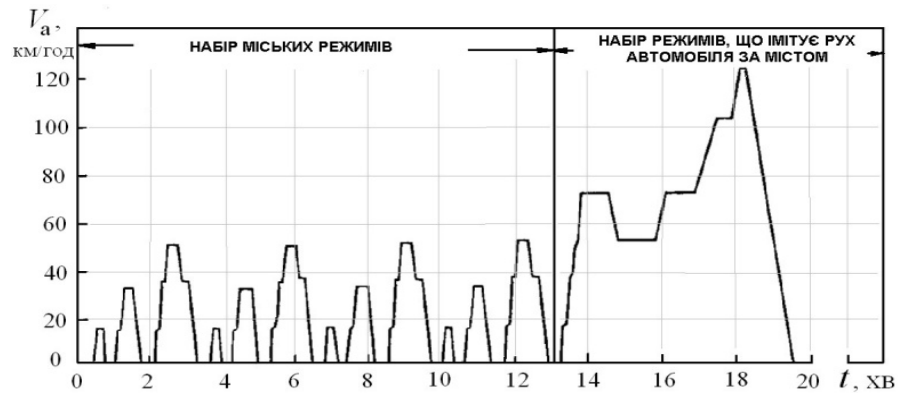

Рисунок 4 - Модифікований Європейський їздовий цикл 


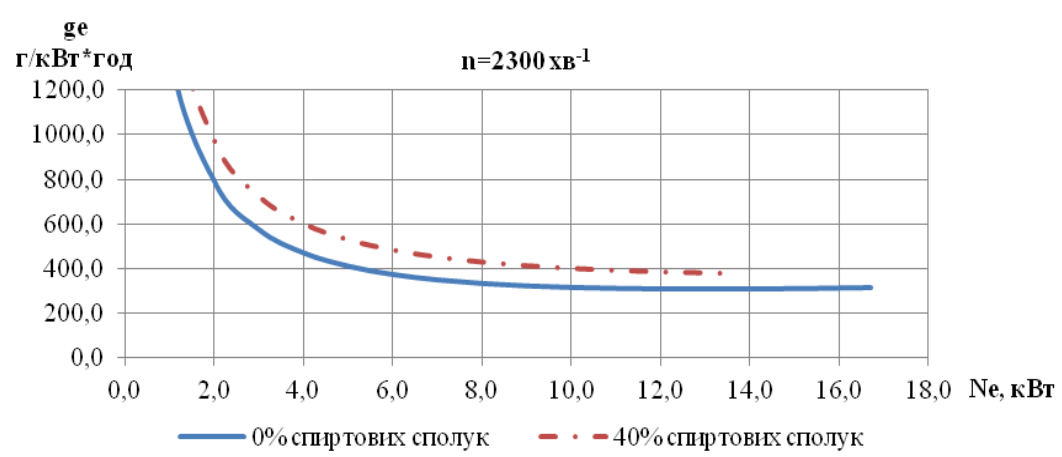

Рисунок 5 - Навантажувальні характеристики двигуна МеМ3-245 отримані під час стендових випробувань автомобіля 3АЗ-1102

Таблиця 1 - Витрата палива у Модифікованому Свропейському їздовому циклі

\begin{tabular}{|l|c|c|c|c|c|}
\hline & \multicolumn{5}{|c|}{ Витрата палива за цикл, г } \\
\cline { 2 - 6 } & $\begin{array}{c}\text { 1-й фрагмент } \\
\text { міського циклу }\end{array}$ & $\begin{array}{c}\text { 2-й фрагмент } \\
\text { міського циклу }\end{array}$ & $\begin{array}{c}\text { 3-й фрагмент } \\
\text { міського циклу }\end{array}$ & $\begin{array}{c}\text { 4-й фрагмент } \\
\text { міського циклу }\end{array}$ & Заміський цикл \\
\hline Бензин А-95 & 70,86 & 68,15 & 67,85 & 66,98 & 280,45 \\
\hline Бензин А-95 Е40 & 82,42 & 83,79 & 82,41 & 83,64 & 332,04 \\
\hline
\end{tabular}

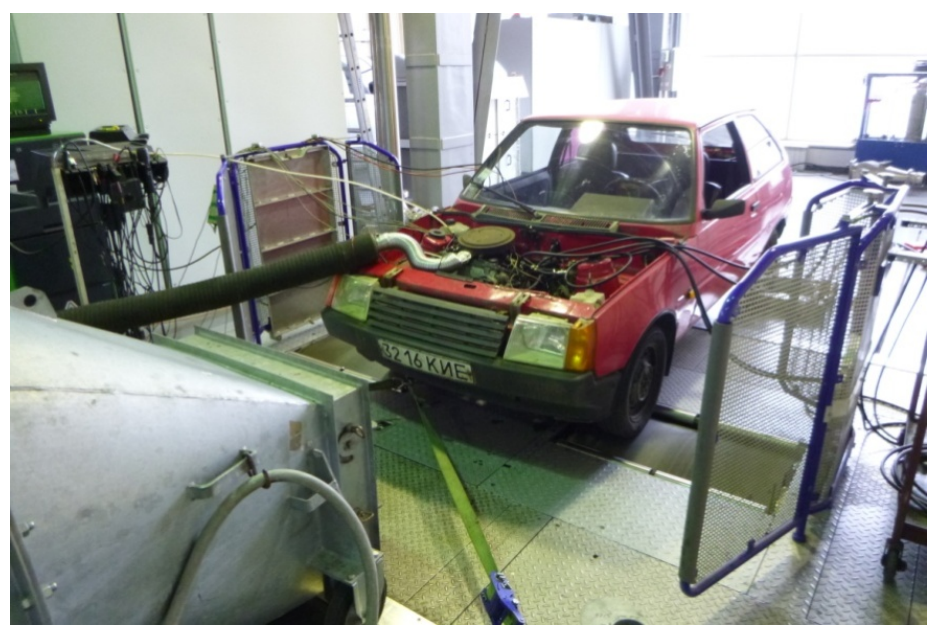

Рисунок 6 - Автомобіль 3АЗ-1102 на випробувальному стенді

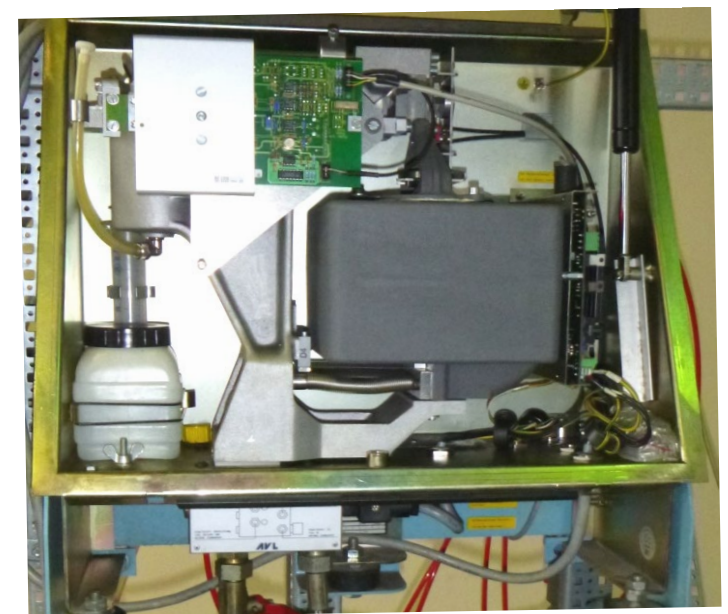

Рисунок 7 - Гравіметричний витратомір AVL 733S

\section{ОБГОВОРЕННЯ РЕЗУЛЬТАТІВ ДОСЛІДЖЕННЯ}

Такі зміни показників паливної економічності автомобіля можна пояснити в першу чергу меншою питомою енергією біоетанолу у порівнянні 3 бензином, більшою його в'язкістю, що 
пояснюються меншою необхідною кількістю повітря для згоряння 1 кг палива та збільшеною прихованою теплотою випаровування і призводить до значного збіднення паливо-повітряної суміші та, як наслідок, погіршення енергетичних показників. Одним 3 можливих шляхів поліпшення енергетичних показників та показників паливної економічності автомобілів, обладнаних двигунами 3 карбюраторною системою живлення при роботі на бензині зі значними за величиною добавками біоетанолу є підігрів паливо-повітряної суміші [9] або зміна регулювань системи живлення, а саме заміна головних паливних жиклерів на такі, що мають більшу пропускну здатність.

Для прикладу на рисунку 8 показані експериментальні значення коефіцієнту надміру повітря одержані при збільшенні пропускної здатності головного паливного жиклера на 10\% [11]. 3 показаних характеристик видно, що двигун нормально працює у всьому діапазоні навантажень.

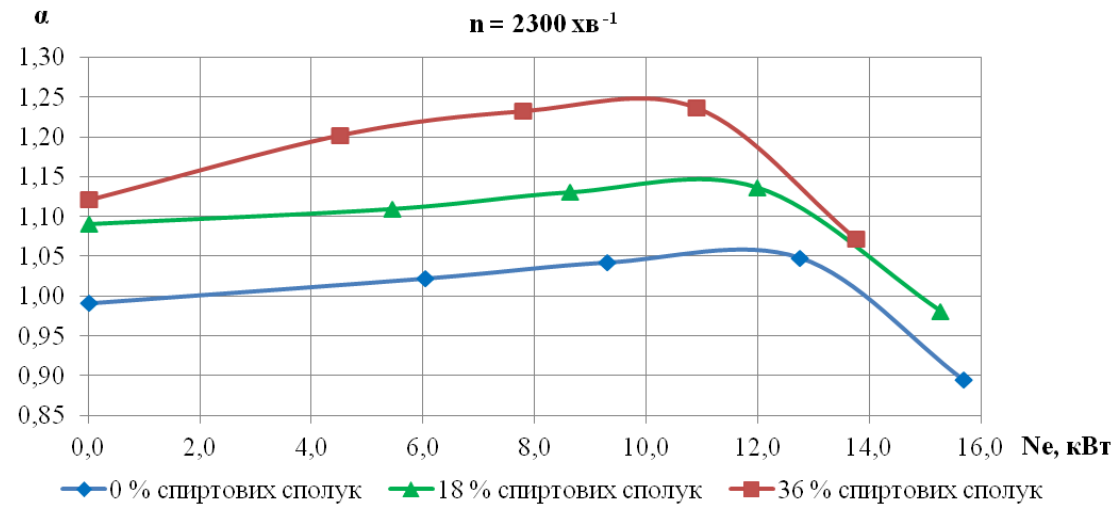

Рисунок 8 - Експериментальні значення коефіцієнту надміру повітря для різних за величиною добавок спиртових сполук до бензину двигуна МеМЗ-245 при зміненому регулюванні карбюратора

\section{ВИСНОВКИ}

Створено математичні моделі двигунів МеM3-245 i VW BBY з використанням яких можливо описати двигун як джерело енергії, споживача палива, повітря та забруднювача навколишнього середовища в навантажувальних режимах роботи та режимах активного і примусового холостих ходів, що необхідно для розрахунку показників автомобілів в русі згідно Модифікованим Європейським їздовим циклом. Під час стендових випробувань автомобіля 3АЗ-1102 встановлено, що при використанні сумішевого бензину з вмістом 40\% спиртових сполук питома витрата палива збільшується до $20 \%$. Для роботи карбюраторного двигуна на бензині з високим вмістом біоетанолу за низьких температур навколишнього середовища необхідна зміна налаштувань системи живлення, а саме - заміна головних паливних жиклерів на такі, що мають більшу пропускну здатність.

\section{ПЕРЕЛІК ДЖЕРЕЛ ПОСИЛАННЯ}

1. Ирисов А. С. Спирт как моторное топливо / А. С. Ирисов. - Москва-Ленинград, Научнотехническое издание по машиностроению, металлообработке и черной металлургии, 1933. - $136 \mathrm{c.}$

2. Климчук О.В., Висоцька В.В. Виробництво біоетанолу-перспективна галузь в Україні / Климчук О.В., Висоцька В.В.// Збірник наукових праць ВНАУ №1(56) Том 32012 С. 98-103.

3. Вильданов Ф.Ш., Латыпова Ф.Н., Чанышев Р.Р, Николаева С.В. Современные методы получения биоэтанола / Вильданов Ф.Ш., Латыпова Ф.Н., Чанышев Р.Р, Николаева С.В // Башкирский химический журнал - 2011 № 2. С. 128-134.

4. Industry Statistic World Fuel Ethanol Production [Virtual Resource] / Access Mode : URL : http://ethanolrfa.org/resources/industry/statistics/\#1454098996479-8715d404-e546 - Title from Screen/ Date of Access: 14 November 2019.

5. Редзюк А.М., Рубцов В.О., Устименко В.С., Михненко Є.О., Олійников О.П. Проблеми та перспективи застосування сумішних бензинів з високооктановою кисневмісною добавкою як автомобільного палива // Автошляховик України. Окр. вип. Вісник Центрального наукового центру ТАУ.- Вип. 2.-1999.-С.25-27. 
6. ГСТУ 320.00149943.015-2000. Бензини моторні сумішеві. Технічні умови (зі змінами №1 від 01.11.2002 і №2 від 25.04.2005).-К.: Держнафтогазпром України, 2000.-24 с.

7. Устименко В.С. Поліпшення екологічних показників автомобілів та розширення паливної бази автомобільного транспорту шляхом застосування біоетанолу : автореф. дис. канд. техн. наук : 05.22.20 / Устименко Віктор Сергійович; Національний транспортний університет. К., 2006. - 21 с.

8. Захарченко О.М. Покращення паливної економічності та екологічних показників автомобілів раціональним використанням бензинів 3 добавкою біоетанолу : автореф. дис. канд. техн. наук : 05.22.20 / Захарченко Олексій Миколайович; Національний транспортний університет. К., 2008. - 20 c.

9. Щербатюк В.Б. Покращення екологічних показників двигунів підігрівом свіжого заряду при використанні бензину з добавкою біоетанолу : автореф. дис. канд. техн. наук : 05.05.03 / Щерба тюк Віталій Броніславович; Національний транспортний університет. К., 2013. - 20 с.

10. Кульбако В.П. Покращення екологічних показників автомобіля в експлуатаційних умовах добавкою біоетанолу до бензину : автореф. дис. канд. техн. наук : 05.22.20 / Кульбако Валентин Петрович; Національний транспортний університет. К., 2012. - 20 с.

11. Гутаревич Ю.Ф. Вплив величини добавки спиртових сполук до бензину на показники роботи карбюраторного двигуна. / Ю.Ф. Гутаревич, Є.В. Шуба, Д.В. Овчинніков // Вісник Національного транспортного університету. - К. : НТУ, 2018. - Вип. 42.

\section{REFERENCES}

1. Irisov A. S. (1933) Spirt kak motornoe toplivo [Ethanol as motor fuel]. Moskva-Leningrad: Nauchno-tehnicheskoe izdanie po mashinostroeniyu, metalloobrabotke i chernoy metallurgii - Scientific and technical publication on mechanical engineering, metal working and ferrous metallurgy, 136 [in Russion].

2. Klymchuk O.V., Vysotska V.V. (2012) Vyrobnytstvo bioetanolu-perspektyvna haluz v Ukraini [Bioethanol production is a promising industry in Ukraine]. Zbirnyk naukovykh prats VNAU - Collection of scientific works of VNAU, №1(56), Tom 3, 98-103 [in Ukrainian].

3. Vildanov F.Sh., Latyipova F.N., Chanyishev R.R, Nikolaeva S.V. (2011) Sovremennyie metodyi polucheniya bioetanola [Modern methods for producing bioethanol]. Bashkirskiy himicheskiy zhurnal Bashkir Chemical Journal, 2, 128-134 [in Russion].

4. Industry Statistic World Fuel Ethanol Production [Virtual Resource] / Access Mode : URL : http://ethanolrfa.org/resources/industry/statistics/\#1454098996479-8715d404-e546 - Title from Screen/ Date of Access: 14 November 2019.

5. Redzyuk A.M., Rubtsov V.O., Ustymenko V.S., Mykhnenko YE.O., Oliynykov O.P. Problemy ta perspektyvy zastosuvannya sumishnykh benzyniv z vysokooktanovoyu kysnevmisnoyu dobavkoyu yak avtomobil'noho palyva // Avtoshlyakhovyk Ukrayiny. Okr. vyp. Visnyk Tsentral'noho naukovoho tsentru TAU.- Vyp. 2.-1999.-S.25-27 [in Ukrainian].

6. HSTU 320.00149943.015-2000. Benzyny motorni sumishevi. Tekhnichni umovy (zi zminamy №1 vid 01.11.2002 i №2 vid 25.04.2005).-K.: Derzhnaftohazprom Ukrayiny, 2000.-24 s [in Ukrainian].

7. Ustymenko V.S. (2006) Polipshennia ekolohichnykh pokaznykiv avtomobiliv ta rozshyrennia palyvnoi bazy avtomobilnoho transportu shliakhom zastosuvannia bioetanolu [Improving environmental performance of cars and expanding the fuel base of road transport by using bioethanol]. Extended abstract of candidate's thesis. Kyiv: NTU [in Ukrainian].

8. Zakharchenko O.M. (2008) Pokrashchennia palyvnoi ekonomichnosti ta ekolohichnykh pokaznykiv avtomobiliv ratsionalnym vykorystanniam benzyniv z dobavkoiu bioetanolu [Improvement of fuel economy and ecological indicators of cars by rational use of gasoline with bioethanol additive]. Extended abstract of candidate's thesis. Kyiv: NTU [in Ukrainian].

9. Shcherbatiuk V.B. (2013) Pokrashchennia ekolohichnykh pokaznykiv dvyhuniv pidihrivom svizhoho zariadu pry vykorystanni benzynu $\mathrm{z}$ dobavkoiu bioetanolu [Improvement of environmental indicators of engines with heating of fresh charge with the use of gasoline with the addition of bioethanol. Extended abstract of candidate's thesis. Kyiv: NTU [in Ukrainian].

10. Kulbako V.P. (2012) Pokrashchennia ekolohichnykh pokaznykiv avtomobilia v ekspluatatsiinykh umovakh dobavkoiu bioetanolu do benzynu [Improvement of the environmental 
performance of the car under operating conditions by adding bioethanol to gasoline]. Extended abstract of candidate's thesis. Kyiv: NTU [in Ukrainian].

11. Hutarevych YU.F. Vplyv velychyny dobavky spyrtovykh spoluk do benzynu na pokaznyky roboty karbyuratornoho dvyhuna. / Y.F. Hutarevych, YE.V. Shuba, D.V. Ovchynnikov // Visnyk Natsional noho transportnoho universytetu. - K. : NTU, 2018. - Vyp. 42[in Ukrainian].

\section{Ovchynnikov. Effect of the composition of mixed gasoline on energy indicators and fuel economy of vehicles with different engine power systems.}

The work presents the results of theoretical and experimental research of the influence of gasoline with a high alcohol content on the performance of engines and vehicles with different fuel systems.

The main attention is paid to the use of this gasoline in vehicles with a carburetor fuel system. In the research has shown the changes main performance vehicle indicators, such as fuel efficiency indicators.

As a result of experimental studies, it was found that with constant regulation of the carburetor, the increase in the content of alcohol in gasoline to $36 \%$ leads to a significant depletion of fuel and air mixture, passage of working cycles, the growth of concentrations of unburned hydrocarbons and lower engine power. To improve the performance of the vehicles with a carburetor fuel system engines for work on gasoline with a significant addition of alcohol compounds, it is proposed to change the regulation of the fuel system towards the enrichment of fuel and air mixture by increasing the throughput of fuel jets. With the corresponding adjustment of the fuel system with an increase in the content of alcohol in gasoline, the engine runs stably without the passes of working cycles. Insignificantly, the maximum engine power decreases and fuel consumption increases, which can be explained by the depletion of the fuel mixture with an increase in the content of alcohol in gasoline.

Polynomial dependences of engine performance on the concentration of alcohol compounds, torque, and engine speed were obtained. They allow the engine to be described as a source of energy, fuel, air and environmental pollutant in load and idle modes, which is necessary to calculate the performance of vehicles in motion according to the Modified European Driving Cycle.Shown the chassis dynamometer test results of ZAZ-1102.

Key words: bioethanol, alcohol compounds, gasoline engine, fuel efficiency, chassis dyno tests.

ОВЧИННІКОВ Дмит ро Володимирович, аспірант кафедри двигунів та теплотехніки, Національний транспортний університет e-mail: dovchinnikov@ukr.net, orcid.org/0000-0003-4938-4503

Dmytro OVCHYNNIKOV, Postgraduate Student of engines and thermal engineering department, National Transport University, Kyiv, Ukraine, dovchinnikov@ukr.net, orcid.org/0000-0003-4938-4503

Автор висловлює окрему вдячність Ричку Сергію Олексійовичу, провідному інженеру лабораторії дослідження використання палив та екології, та Назаренку Юрію Валерійовичу, інженеру 2-ї категорії лабораторії дослідження використання палив та екології ДП «ДержавтотрансНДІпроект». 